\title{
Detection of Bovine Viral Diarrhea virus infection in newborn calves before colostrum intake
}

\section{Detecção da infecção pelo Vírus da Diarreia Viral Bovina em recém- nascidos antes da ingestão de colostro}

\author{
Camila Cecilia Martin ${ }^{1 *}$; Camila Costa Baccili²; Bruno Toledo Silva ${ }^{1}$; \\ Sylvia Marquart Fontes Novo ${ }^{1}$; Natália Meirelles Sobreira ${ }^{3}$; \\ Edviges Maristela Pituco ${ }^{4}$; Viviani Gomes ${ }^{5}$
}

\begin{abstract}
The detection of Bovine Viral Diarrhea virus (BVDV) infection, especially among persistently infected calves (PI), should be performed earlier in order to eliminate the source of the infection and to prevent the spread of the disease in the herd. However, colostrum intake can influence the results of some of the tests used to diagnose the BVDV infection. Therefore, this study evaluated the efficacy of serum neutralization (SN) test in conjunction with reverse transcription-polymerase chain reaction (RT-PCR) for the diagnosis of BVDV infection before colostrum intake. The deliveries of the animals were assisted to select 52 newborn Holstein calves for inclusion in the study. Initially, the whole blood and serum samples were collected from the calves before (T0) and after (T1) the colostrum intake. The calves that were RT-PCR positive at any of the time-points were retested on the $30^{\text {th }}$ day post birth (T2). The presence of specific antibodies for BVDV was evaluated by SN, and that of viral RNA by the RT-PCR. The BVDV-specific antibodies were observed in the serum of $13.46 \%(7 / 52)$ of the calves at T0 because of fetal infection. At T1, seroconversion was observed in $100 \%(52 / 52)$ of the calves. The geometric mean titers (GMT) of the antibodies for BVDV increased significantly from T0 (14.52) to T1 (2490) $(P=0.0001)$. Of the four calves that were RT-PCR positive before colostrum intake (T0), two were seronegative and two, seropositive. Of the forty-eight RT-PCR negative calves, five were seropositive. After 30 days post birth, all of the animals tested negative by RT-PCR, thus excluding the possibility of persistent infection. The association observed between the results of the SN and RT-PCR assays at T0 $(P=0.025)$ could not be observed at T1 $(P>0.05)$. The SN test before the colostrum intake allowed the detection of fetal infection in the herd; however, this test was ineffective as a diagnostic method after the transfer of passive immunity. The confirmation of the results of the SN assay by those of the RT-PCR was essential for the identification of the infected calves before colostrum intake.
\end{abstract}

Key words: Bovine viral diarrhea. Passive immunity. Persistent infection. Polymerase chain reaction. Serum neutralization.

\section{Resumo}

Infecção causada pelo BVDV, especialmente bezerras persistentemente infectadas (PI), deve ser detectada precocemente para eliminação da fonte de infecção e disseminação da doença no rebanho.

\footnotetext{
${ }^{1}$ Discentes do Curso de Mestrado, Faculdade de Medicina Veterinária e Zootecnia, Universidade de São Paulo, USP, São Paulo, SP, Brasil. E-mail: camilacmartin@gmail.com; bruno.toledo@usp.br; sylvia.novo@usp.br

${ }^{2}$ Discente do Curso de Doutorado, Faculdade de Medicina Veterinária e Zootecnia, USP, São Paulo, SP, Brasil. E-mail: camila. rcosta@usp.br

${ }^{3}$ Médica Veterinária autônoma, Araras, SP, Brasil. E-mail: nasobreira@gmail.com

${ }^{4}$ Pesquisadora, Instituto Biológico, São Paulo, SP, Brasil. E-mail: pituco@biologico.sp.gov.br

${ }^{5}$ Prof ${ }^{\text {a }}$ Faculdade de Medicina Veterinária e Zootecnia, USP, São Paulo, SP, Brasil. E-mail: viviani.gomes@usp.br

* Author for correspondence
} 
No entanto, a mamada de colostro interfere em alguns testes adotados para o diagnóstico da Diarréia Viral Bovina. Assim, esta pesquisa avaliou o uso da soroneutralização (SN) em associação com a reação em cadeia de polimerase precedida da transcrição reversa (RT-PCR) para diagnóstico da infecção pelo BVDV antes da mamada de colostro. Partos foram acompanhados para seleção de 52 bezerras da raça Holandesa. Inicialmente foram coletadas amostras de sangue total e soro de todos os animais antes (T0) e após a mamada do colostro (T1). Os animais positivos no RT-PCR em qualquer momento foram retestados aos 30 dias de vida (T2). A detecção de anticorpos específicos para o BVDV foi feita por meio da técnica de soroneutralização e a detecção do RNA viral pela técnica de RT-PCR. Foram observados anticorpos neutralizantes no soro sanguíneo em $13,46 \%$ (7/52) bezerras no T0, proveniente de infecção fetal; e no T1 observou-se soroconversão de 100\% (52/52) das bezerras. Os títulos médios geométricos (GMT) de anticorpos para BVDV aumentaram significativamente do T0 $(14,52)$ para o T1 $(2.490)$ $(\mathrm{P}=0,0001)$. Quatro bezerros foram positivos no RT-PCR antes da mamada de colostro (T0), sendo que dois deles eram soronegativos e dois soropositivos; e entre os animais RT-PCR negativos $(n=48)$, cinco deles apresentavam-se soropositivos. Após 30 dias de vida todos os animais apresentaram resultado negativo no RT-PCR, excluindo-se a possibilidade de infecção persistente. Detectou-se associação entre a soroneutralização e o RT-PCR no T0 $(\mathrm{P}=0,025)$, fato não observado em T1 $(\mathrm{P}>0,05)$. A avaliação da sorologia antes da mamada de colostro permitiu a identificação da infecção fetal no rebanho, porém essa prova foi invalidada como método de diagnóstico após a transferência de imunidade passiva. A associação entre SN e RT-PCR foi fundamental para detecção da infecção provocada pelo BVDV antes da ingestão do colostro.

Palavras-chave: Diarreia viral bovina. Imunidade passiva. Infecção persistente. Reação em cadeia de polimerase. Soroneutralização.

\section{Introduction}

The reported prevalence of the BVDV infections among the unvaccinated cattle herds from the states of Sao Paulo and Minas Gerais, Brazil were $94.7 \%, 45.8 \%$, and $76.8 \%$ for the beef, dairy, and combined production systems, respectively (ALEXANDRINO et al., 2011). The economic burden inflicted by BVDV infection is directly related to the costs of the diagnosis, treatment, vaccination, decline in production, and decrease in conception rates, besides the restrictions on the trade of the animals (CORNISH et al., 2005; PILZ et al., 2005; OIE, 2014).

The impact of BVDV infection on the reproduction of the affected animals is related to the ability of the virus to reach the reproductive system and cross the placental barrier during pregnancy. The fetal infection by the non-cytopathic virus between 40 and 120 days of pregnancy might lead to the birth of immunotolerant and persistently infected (PI) animals because of the inability of the yet-immature fetal immune system to differentiate between viral proteins and self-proteins (KELLING; TOPLIFF,
2013). Consequently, PI animals born is the critical point in the epidemiological chain of the disease (RIBEIRO; PEREIRA, 2004; FLORES et al., 2005; PILZ et al., 2005; ARENHART et al., 2009). Infection during the second trimester of pregnancy, between 100 and 150 days, is associated with the changes in fetal organogenesis and teratogenicity. From the third trimester of pregnancy, the virus usually does not cause disease because of the ability of the fetus to develop an immune response and produce BVDV-specific antibodies (GROOMS et al., 2006; DABAK et al., 2007; RIDPATH, 2010).

The birth rate of the PI animals is 1-2\% (PILZ et al., 2005), and the lethality of such calves within the first year of birth is approximately $50 \%$ because of their prematurity (BAKER, 1987). The persistent infection-survivor calves might have mucosal diseases or might reach adulthood all the while continuously spreading the virus in the herd through their secretions (HOUE et al., 2006).

BVDV infection is diagnosed by serological tests through the detection of the virus or viral antigens. Recent studies have suggested the use of the clinical 
samples obtained before the colostrum intake for the identification of the PI animals (SCHEFERS et al., 2008; LANYON et al., 2014), because the newborn calves would be negative for the presence of the viral antigens in the absence of the exposure to BVDV. In contrast, the calves will be seropositive for BVDV infection from 120 days post conception because of the ability of their now-mature immune system to mount an immune response to the viral infection (KELLING; TOPLLIF, 2013).

After the administration of colostrum, the calves acquire the maternal antibodies and become seropositive, rendering the serological tests for the diagnosis of BVDV inefficient. The indirect immunoenzymatic assays are indicated from the $10^{\text {th }}$ week post birth, when a significant decrease in the colostral antibodies can be observed (LAUREYNS et al., 2010).

In order to counteract this issue, the correlation between the results of the serological tests and the direct evidence of the infective agent are essential. The molecular diagnostic tests are fast and suitable for the detection of even small concentrations of the BVDV viral RNA with high sensitivity and specificity. In this context, the reverse transcriptionpolymerase chain reaction (RT-PCR) has been widely used for the identification of the PI calves, primarily because the results do not suffer from the interference of the maternal antibodies (PILZ et al., 2005, 2007; DUBOVI, 2013; FUX; WOLF, 2012).

In order to avoid the major problems associated with the presence of BVDV in livestock and to minimize the economic losses, herd immunization and the elimination of the PI animals have been advocated as solutions (RIBEIRO; PEREIRA, 2004). The detection of BVDV should be performed in the early stages of the infection in order to eliminate the source and spread of the disease in the herd. The interference of maternal antibodies, transferred to calves after colostrum intake, with the diagnostic assays suggest evaluation of the animal immediately after birth and before the passive transfer of immunity.
The hypothesis of this study is that the evaluation of calves before colostrum intake can be an effective strategy for the early identification of fetal infection. Towards this, the aim of this study was to evaluate the utility of performing the RT-PCR assay in conjunction with the serum neutralization (SN) test, before the colostrum intake for the detection of fetal BVDV infection.

\section{Material and Methods}

\section{Animals and samples}

This study was conducted in 2014 in a highproduction dairy farm located in Araras, Sao Paulo, Brazil. A total of 52 female newborn Holstein calves that were fed frozen colostrum pooled from the herd animals that were vaccinated for BVDV. The farm practiced prophylactic vaccination of calves at 6 months of age, with a subsequent booster dose 30 days thereafter, and semi-annual revaccination in the months of April and October, starting from puberty at the $11^{\text {th }}$ month post birth.

The pregnant cows included in this study were vaccinated against BVDV, and were housed in the maternity paddocks from 30 days before the expected parturition date until the time of calving. All births were assisted, and the calves were separated immediately after birth and transferred to individual pens. Four liters of the frozen colostrum from the first milking were administered in two feeding sessions during the first 12 hours after the birth. The colostrum was obtained from multiparous donors whose immune quality was estimated using a colostrometer ( $\geq 50 \mathrm{~g} / \mathrm{L}$ of immunoglobulin). The thawing was performed in a water bath $\left(45-50^{\circ} \mathrm{C}\right)$ until the colostrum reached a temperature of $37^{\circ} \mathrm{C}$. After the colostrum administration to the calves, they were fed six liters of a milk replacer (Lacthor ${ }^{\circledR}$ - Tortuga, Sao Paulo, Brazil) per day.

Blood samples from the calves were collected with vacutainer tubes containing Ethylenediamine Tetraacetic Acid (EDTA), but without an anticoagulant, before the feeding of the colostrum 
(T0) and on the $2^{\text {nd }}$ day post birth (T1). In order to detect the PI animals with BVDV, additional analyses were performed at 30 days post birth (T2) only on those calves that were found to be RT-PCR positive at $\mathrm{T} 0$ and/or $\mathrm{T} 1$.

\section{Serum neutralization}

The detection of the BVDV-specific antibodies was performed by the SN test in the Bovine Virus Laboratory - Biological Institute, according to the recommendations from the World Organization for Animal Health (2008). The detection of the antiBVDV neutralizing antibodies was performed after prior inactivation of the blood serum at $56^{\circ} \mathrm{C}$ for 30 minutes. The starting dilutions of the serum from 1:4 to $1: 5120$ in the minimal essential medium (MEM) were added to the 96-well polystyrene plates. Then, each of the diluted samples received a $50 \mu \mathrm{L}$ stock solution containing $100 \mathrm{TCID}_{50}$ of the NADL cytopathogenic strain of BVDV. The plates were incubated for $1 \mathrm{~h}$ at $37^{\circ} \mathrm{C}$ with $5 \% \mathrm{CO}_{2}$. Subsequently, $50 \mu \mathrm{L}$ of Madin-Darby bovine kidney (MDBK) cell suspension was added to each of the wells at a concentration of $3 \times 10^{5}$ cells $/ \mathrm{mL}$. The plates were again incubated at $37^{\circ} \mathrm{C}$ with $5 \% \mathrm{CO}_{2}$ for 4-5 days.

The infectivity was measured on the basis of the cytopathic effect (CPE) of the BVDV infection visible in the monolayer cell of the plates, under an inverted microscope. The antibody titer was expressed as the highest dilution of the serum that completely inhibited the infectivity and, therefore, the CPE, in both the wells of each dilution, according to the Reed-Muench method (1938).

The samples presenting anti-BVDV antibody titers below or above 10 were considered negative and positive, respectively.

\section{Reverse transcriptase-polymerase chain reaction}

The whole blood samples were homogenized by inverting 10 times, and the tubes were centrifuged at $1200 \mathrm{rpm}$ for 15 minutes at $22^{\circ} \mathrm{C}$ (room temperature). After centrifugation, the plasma was discarded, and the leukocyte layer was removed and preserved for analysis by the RT-PCR.

The nucleic acid extraction was performed using the TRIZOL Reagent LS $^{\circledR}$ (Invitrogen, Carlsbad, USA). The RT-PCR was performed using a commercial kit (Access Quick ${ }^{\mathrm{TM}}$ RT-PCR System, Promega, Madison, USA), according to the manufacturer's instructions.

The primers used in this reaction were specific to a sequence of 290 nucleotides located in the 5'-untranslated region (5'-TAG TAG TAG CCT CCA GCT GAC-3' and 5'-ACT TGT CCA GCC ATG TAC AGC-3') common to the BVDV-1 and 2 serotypes (PILZ et al., 2007). The amplified product was electrophoresed in a $1.5 \%$ agarose gel in $1 \mathrm{X}$ TBE buffer at $100 \mathrm{~V}$ for one hour. The amplicons were visualized after staining with diluted red gel (1:150) in nuclease free water (Promega, Madison, USA), using the transilluminator under ultraviolet light (320 nm). The DNA fragments were compared with the standard base pairs presenting increments of $100 \mathrm{bp}$ (100 bp DNA ladder, Invitrogen, Carlsbad, USA). The samples were considered positive if the amplicon of the tested sample presented a band of the same size as the positive control, and negative in the absence of a band corresponding to the size of that of the positive control.

\section{Statistical analysis}

The statistical analyses were performed using the statistical program GraphPad Instat, version 3.0 (La Jolla, CA, USA) (GRAPHPAD INSTAT, 2008). The data were first tested using the KolmogorovSmirnov test, which verified that some of the variables were not normally distributed; therefore, we opted for the non-parametric tests.

The analysis of anti-BVDV neutralizing antibody titers was performed using both the qualitative and quantitative tests. The calves that presented the 
antibody titers greater than 1:10 were considered seropositive.

The antibody titers (1:10 to $1: 5120)$ were transformed to their logarithmic values by considering a 1:10 serum dilution as $\log _{2}=$ zero. The mean of the $\log _{2}$ values were calculated at the T0 and T1 time points. The mean $\log _{2}$ values were transformed into their geometric mean titers (GMT) by the ratio GMT $=2^{\mathrm{a}}$, where " $\mathrm{a}$ " is the arithmetic mean of the log of the antibody titers (THRUSFIELD, 2004).

The calves were divided into two groups according to their RT-PCR results at each of the time points. The correlation between the frequencies of the positive and negative results for both the SN and RT-PCR assays at each time point was determined by the chi-square test.

\section{Results and Discussion}

This study evaluated the concomitant use of the SN and RT-PCR assays for the diagnosis of fetal infection by BVDV, using the blood samples obtained before colostrum intake. Additionally, we were able to analyze the influence of the maternal antibodies on the results of the diagnostic tests selected.

The presence of the anti-BVDV neutralizing antibodies was observed in $13.46 \%(7 / 52)$ of the calves before the colostrum intake (T0). Considering that the bovine placenta is syndesmochorial and does not allow the transfer of the maternal antibodies to the fetus during gestation (FUX; WOLF, 2012), it can be concluded that the presence of the antiBVDV neutralizing antibodies at T0 was due to the fetal infection in the animals. The infected fetuses in the third trimester of the pregnancy do not show any clinical signs of disease at birth; since organogenesis would have already been completed and the immune system fully developed, resulting in the development of antibodies against the virus and consequent seropositive at birth (STOKSTAD; LOKEN, 2002; SCHEFERS et al., 2008; KELLING; TOPLLIF, 2013). According to Sarrazin et al. (2014) the seroconversion occurs between 11 and 17 days, and the neutralizing antibodies in the blood can reach their peak titer between 9 and 12 weeks post infection.

After the colostrum intake (T1), seroconversion was observed in $100 \%(52 / 52)$ of the calves that ingested the colostrum from the cows that had been vaccinated against BVDV, thus proving the efficient transfer of the anti-BVDV neutralizing antibodies through the colostrum of the multiparous cows. A significant correlation was observed between the results of the SN test and the time points of the serum collection $(P=0.0001)$ (Table 1). Calves are hypogammaglobulinemic at birth, and depend on the colostrum intake to obtain BVDV-specific antibodies by the passive transfer of immunity (CHASE et al., 2008).

Table 1. Frequencies of the seropositive and seronegative calves in the serum neutralization test for BVDV before (T0) and after the colostrum intake (T1).

\begin{tabular}{|c|c|c|c|c|c|}
\hline \multirow{2}{*}{ SN } & \multicolumn{2}{|c|}{ T0 } & \multicolumn{2}{|c|}{$\mathrm{T} 1$} & \multirow{2}{*}{$P$-value } \\
\hline & $\mathrm{N}$ & $\%$ & $\mathrm{~N}$ & $\%$ & \\
\hline$(+)$ & 7 & 13.46 & 52 & 100 & \multirow{2}{*}{0.0001} \\
\hline$(-)$ & 45 & 86.54 & 0 & 0 & \\
\hline
\end{tabular}

BVDV, Bovine Viral Diarrhea Virus; SN, Serum neutralization test; T0, before colostrum intake; T1, after colostrum intake 
The GMT of the BVDV-antibodies had increased from 14.52 at $\mathrm{T} 0$ to 2490 at $\mathrm{T} 1(P=0.0001)$ (Table $2)$. These findings support the theory of the transfer of the anti-BVDV neutralizing antibodies after the ingestion of the colostrum. The distribution of the frequency of the animals according to the antibody titers is shown in Table 3.

Table 2. Geometric mean titers (GMT) of the neutralizing antibodies for BVDV in the blood serum obtained from the calves before (T0) and after the colostrum intake (T1).

\begin{tabular}{|c|c|c|c|}
\hline \multicolumn{4}{|c|}{ BVDV } \\
\hline & \multicolumn{2}{|c|}{ Frequency (n) } & \multirow{2}{*}{$P$-value } \\
\hline & T0 & $\mathrm{T} 1$ & \\
\hline Log GMT & 0.54 & 7.96 & \multirow{2}{*}{0.0001} \\
\hline GMTs & 14.52 & 2.490 & \\
\hline
\end{tabular}

BVDV, Bovine Viral Diarrhea Virus; GMT, Geometric mean titers; T0, before colostrum intake; T1, after colostrum intake.

Table 3. Distribution of the frequencies of the calves by the geometric mean titers (GMT $\log _{2}$ ) of the BVDV antibodies.

\begin{tabular}{|c|c|c|c|c|}
\hline \multirow{2}{*}{ GMT $\log _{2}$} & \multicolumn{2}{|c|}{ T0 } & \multicolumn{2}{|c|}{ T1 } \\
\hline & $\mathrm{n}$ & $\%$ & $\mathrm{n}$ & $\%$ \\
\hline 0 & 45 & 86.54 & 0 & 0.00 \\
\hline 1 & 3 & 5.77 & 0 & 0.00 \\
\hline 3 & 0 & 0.00 & 1 & 1.92 \\
\hline 4 & 2 & 3.85 & 0 & 0.00 \\
\hline 5 & 0 & 0.00 & 2 & 3.85 \\
\hline 6 & 0 & 0.00 & 1 & 1.92 \\
\hline 7 & 0 & 0.00 & 10 & 19.23 \\
\hline 8 & 1 & 1.92 & 17 & 32.69 \\
\hline 9 & 1 & 1.92 & 21 & 40.38 \\
\hline
\end{tabular}

BVDV, Bovine Viral Diarrhea Virus; T0, before colostrum intake; T1, after colostrum intake.

The titers of the BVDV antibodies present in the blood serum of the calves after colostrum intake are directly correlated to the concentration of the BVDVspecific antibodies in the mammary secretion. This phenomenon is influenced by diverse factors such as the degree of exposure to the field strains and the adoption of the herd vaccination programs in the farms. The response to the vaccination depends on the frequency of vaccination, number of doses, individual responses of the animals, and the capacity of the animal to transfer the BVDV-specific antibodies through the colostrum (CHAMORRO et al., 2014). The farm included in this study used the colostrum of pluriparous cows, and practiced a vaccination program that administered at least three doses during the first year, and two annual boosters. We believe that these facts are responsible for the high antibody titers observed in our study after colostrum intake.

With regard to the RT-PCR, four of the calves were found to be positive for BVDV before the colostrum feeding (T0), of which, two were seronegative, and two, seropositive. Of the RT-PCR negative calves $(n=48)$, five of them were found to be seropositive (Table 4). The results of the RTPCR, taken together with those of the SN, allow for the confirmation of the presence of fetal infection in the herd at different stages of pregnancy, with 
viral shedding by the pregnant animals before birthing (SCHEFERS et al., 2008; KELLING; TOPLIFF, 2013). In order to evaluate the possibility of seroconversion in the RT-PCR positive animals that were seronegative, the sequential collection of the blood serum from the calves should have been undertaken; however, this was not possible because of the ingestion of the colostrum containing the specific antibodies against BVDV.

Table 4. Number of positive and negative animals for BVDV, based on the RT-PCR results for BVDV infection.

\begin{tabular}{|c|c|c|c|c|c|c|}
\hline \multirow{2}{*}{ Moments } & \multirow{2}{*}{ SN } & \multicolumn{2}{|c|}{ RT-PCR (+) } & \multicolumn{2}{|c|}{ RT-PCR (-) } & \multirow{2}{*}{$P$-value } \\
\hline & & $\mathrm{n}$ & $\%$ & $\mathrm{n}$ & $\%$ & \\
\hline \multirow{2}{*}{ T0 } & $(+)$ & 2 & 3.84 & 5 & 9.62 & \multirow{2}{*}{0.025} \\
\hline & $(-)$ & 2 & 3.84 & 43 & 82.69 & \\
\hline \multirow{2}{*}{$\mathrm{T} 1$} & $(+)$ & 5 & 9.62 & 47 & 90.38 & \multirow{2}{*}{0.975} \\
\hline & $(-)$ & 0 & 0 & 0 & 0 & \\
\hline
\end{tabular}

BVDV, Bovine Viral Diarrhea Virus; RT-PCR, Reverse Transcriptase-Polymerase Chain Reaction; SN, Serum neutralization test; $\mathrm{T} 0$, before colostrum intake; T1, after colostrum intake.

The newborn calves included in this study were subjected to the serological tests for the detection of persistent BVDV infection, as recommended by Dabak et al. (2007). The PI calves should test negative in the serological tests at birth due to the phenomenon of immunological tolerance (STOKSTAD; LOKEN, 2002; DABAK et al., 2007). The biggest challenge with the results of the SN tests of the calves at birth was the need to differentiate between the seronegative PI animals from those not exposed to the virus during the fetal stages. Therefore, the RT-PCR assay was performed to evaluate each of the samples at $\mathrm{T} 0$.

The probability of the PI in the calves of the herd was determined based on the number of the seronegative and RT-PCR positive animals.
However, the repeat RT-PCR assay at 30 days post birth of all animals that had previously tested positive by RT-PCR produced only negative results for BVDV infection (Table 5). According to Ridpath et al. (2012), the standard diagnostic test for PI with BVDV is two positive tests for the virus with samples collected at least 3 weeks apart.

It is very important to conduct the RT-PCR in conjunction with a supporting serological test for identifying the PI animals (VALZ et al., 2010). The calves might carry viral loads in their blood soon after birth because of the fetal infection in the late stages of the pregnancy. These animals might not present antibodies against the virus, but are source of BVDV infection (FINO et al., 2012; RIDPATH et al., 2012; KELLING; TOPLIFF, 2013).

Table 5. Frequency of the RT-PCR positive and negative animals for BVDV before the colostrum intake (T0) and at 48 hours post-partum (T1). The RT-PCR positive animals at T0 and T1 were retested 30 days post-partum (T2).

\begin{tabular}{cccc}
\hline \multirow{2}{*}{ RT-PCR } & \multicolumn{3}{c}{ Frequency $(\mathrm{n})$} \\
\cline { 2 - 4 } & $\mathrm{T} 0$ & $\mathrm{~T} 1$ & $\mathrm{~T} 2$ \\
\hline$(+)$ & 7.69 & 9.61 & 0 \\
$(-)$ & 92.31 & 90.38 & 100 \\
\hline
\end{tabular}

BVDV, Bovine Viral Diarrhea Virus; RT-PCR, Reverse Transcriptase-Polymerase Chain Reaction; T0, before colostrum intake; T1, after colostrum intake; T2, 30 days post-partum. 
After the colostrum intake (T1), all of the calves were seropositive for the BVDV by the SN assay; however, only five of the animals were RT-PCR positive, of which, four had already been found positive at T0. The BVDV incubation period is from 3 to 7 days post-infection (FINO et al., 2012), and thus, we can exclude the possibility of postnatal infection in this study, since the blood samples were collected 48 hours after the birth of the calves.

One of the animals was negative for BVDV at T0, and positive at T1, by RT-PCR. According to Dubovi (2013) some of the animals might display very low viral loads, which might not be detectable by RT-PCR. This might occur early in the infection cycle, when the virus cannot be detected by virus isolation and molecular analyses (FINO et al., 2012). Sarrazin et al. (2014) verified that the calves became RT-PCR positive for BVDV 5 days after the inoculation of the animal with the viral agent.

It is important to highlight that the maternal antibodies might interfere in the diagnostic tests, given that the isolation of BVDV from the blood samples of PI calves can be inhibited by the neutralizing antibodies for several weeks after birth, resulting in the false-negative results of infection assays (ZIMMER et al., 2004; FUX; WOLF, 2012). For this reason, virus isolation was not selected as the diagnostic test for the direct detection of BVDV in this study.

The enzyme-linked immunosorbent assay (ELISA) for the viral antigen in addition to the RTPCR assay is an appropriate protocol for detecting the PI animals among the herd. However, Zimmer et al. (2004) reported that the direct enzyme immunoassay detected only 10 of the 25 PI calves, thus demonstrating the suppressive effect of the maternal antibodies. There is a proportional relationship of the maternal antibody titers with the efficacy of the isolation of the BVDV and the direct enzyme immunoassay, i.e., the higher the mean titer of the maternal antibodies, the lower will be the possibility of virus isolation and the detection of the viral antigens by the enzyme immunoassay, thus indicating the inefficacy of these two techniques in the diagnosis of the PI animals following the ingestion of the colostrum.

Laureyns et al. (2010) indicated the use of the direct enzyme immunoassay assay effective from 10 weeks after birth because of the decrease in maternal antibody levels in the blood serum of calves by the end of this period. Moreover, Bruschke et al. (1998) demonstrated that maternal antibodies of BVDV in the serum of 30-week-old PI calves.

With the combined results of the SN and RTPCR assays of samples before the colostrum intake, we can conclude that viral circulation was present within the herd despite the biannual vaccination for BVDV. The commercial vaccines of BVDV in Brazil contain the inactivated virus, which prevents virus replication in the cells of the hosts and results in a weak post-vaccination immune response. This fact points to the need for adjuvants that effect the modulation and enhancement of the antigen response by increasing the time of retention of antigen in the tissue where the vaccine was injected (DEUTSKENS et al., 2011). Very few studies have evaluated the efficacy of the commercial vaccines for BVDV in Brazil. Apart from the efficacy of the vaccine, it must be noted that the vaccine response depends on the vaccination protocol, nutritional status, and health of the cow.

The research was conducted in a high-production dairy farm with around 3,500 animals, of which 800 female animals had not attained the reproductive age at the time of the study. All animals were raised in an open herd, in which some of the cows with high genetic potential were transferred for embryo collection in Paraná, resulting in the addition of the calves to the herd by other routes. Despite this, the farm did not practiced a routine protocol to detect PI calves until the findings of this research was available. Thus, it is essential to spread the awareness among the farmers of the importance of the early detection of BVDV infection 
The identification of the PI animals within the herd is the key point for the prevention and control of this disease, and should be carefully performed. The success of any eradication and control program for BVDV depends on the ability of the diagnostic tests to detect all PI animals earlier. In this context, it can be stated that the SN test contributed to the identification of the fetal infection in this herd, and when combined with the RT-PCR assay, and allowed for the exclusion neonates that were suspected to be persistently infected with BVDV. Additionally, the serological tests were effective to determine the status of the vaccination and the transfer of passive immunity in this herd, but ineffective for the diagnosis of the disease if performed after the colostrum intake.

\section{Conclusions}

The association between the results of the SN and RT-PCR assays before colostrum intake allowed the detection of the fetal infection and proved the existence of the viral circulation in this herd. Although the SN assay should not be used as a method for the diagnosis of BVDV infection after the colostrum intake, this test showed an effective transfer of passive immunity to the calves after colostrum management.

\section{References}

ALEXANDRINO, B.; DIAS, F. C.; OLIVEIRA, M. C.; AFFONSO, I. B.; PEREIRA, G. T.; SAMARA, S. I. Herpesvirus bovino associado à diarréia viral bovina e à leucose enzoótica bovina. ARS Veterinária, Jaboticabal, v. 27 , n. 3, p. 168-174, 2011.

ARENHART, S.; BAUERMANN, F. V.; OLIVEIRA, S. A. M.; WEIBLEN, R.; FLORES, E. F. Excreção e transmissão do vírus da diarréia viral bovina por bezerros persistentemente infectados. Pesquisa Veterinária Brasileira, Soropédica, v. 29, n. 9, p. 736-742, 2009.

BAKER, J. C. Bovine viral diarrhea virus: a review. Journal of the American Veterinary Medical Association, Schaumburg, v. 190, n. 11, p. 1449-1458, 1987.
BRUSCHKE, C. J. M.; HAGHPARAST, A.; HOEK, A.; RUTTEN, V. P. M. G.; WENTINK, G. H.; RIJIN, P. A.; OIRSCHOT, J. T. The immune response of cattle, persistently infected with noncytopathic BVDV, after superinfection with antigenically semi-homologous cytopathic BVDV. Veterinary Immunology and Immunopathology, Amsterdam, v. 62, n. 1, p. 37-50, 1998.

CHAMORRO, M. F.; WALZ, P. H.; HAINES, D. M.; PASSLER, T.; EARLEYWINE, T.; PALOMARES, R. A.; RIDDELL, K. P.; GALIK, P.; ZHANG, Y.; GIVENS, M. D. Comparison of levels and duration of detection of antibodies to bovine viral diarrhea virus 1 , bovine viral diarrhea virus 2, bovine respiratory syncytial virus, bovine herpesvirus 1 , and bovine parainfluenza virus 3 in calves fed maternal colostrum or a colostrumreplacement product. Canadian Journal of Veterinary Research, Ottawa, v. 78, n. 2, p. 81-88, 2014.

CHASE, C. C. L.; HURLEY, D. J.; REBER, A. J. Neonatal immune development in the calf and its impact on vaccine response. Veterinary Clinics of North America: Food Animal Practice, Philadelphia, v. 24, n. 1, p. 87-104, 2008.

CORNISH, T. E.; OLPHEN, A. L.; CAVENDER, J. L.; EDWARDS, J. M.; JAEGER, P. T.; VIEYRA, L . L.; WOODARD, L. F.; MILLER, D. R.; O'TOOLE, D. Comparison of ear notch immunohistochemistry, ear notch antigen-capture ELISA, and buffy coat virus isolation for detection of calves persistently infected with bovine viral diarrehea virus. Journal of Veterinary Diagnostic Investigation, Athens, v. 17, n. 2110, p. 110117, 2005.

DABAK, M.; KARAPINAR, T.; GULACTI, I.; BULUT, H.; KIZIL, O.; AYDIN, S. Hemorrhagic syndromelike disease in calves with bovine viral diarrhea and mucosal disease complex. Journal of Veterinary Internal Medicine, Louisiania, v. 21, n. 3, p. 514-518, 2007.

DEUTSKENS, F.; LAMP, B.; RIEDEL, C. M.; WENTZ, E.; LOCHNIT, G.; DOLL, K.; RÜMENAPF, T. Vaccineinduced antibodies linked to bovine neonatal pancytopenia (BNP) recognize cattle major histocompatibility complex class I (MHC I). Veterinary Research Communications, Edinburgh, v. 42, n. 1, p. 93-97, 2011.

DUBOVI, E. J. Laboratory diagnosis of bovine viral diarrhea virus. Biologicals, London, v. 41, n. 1, p. 8-13, 2013.

FINO, T. C. M.; MELO, C. B.; RAMOS, A. F.; LEITE, R. C. Diarréia bovina a vírus (BVD) - uma breve revisão. Revista Brasileira de Medicina Veterinária, Niterói, v. 32, n. 2, p. 131-140, 2012. 
FLORES, E. F.; WEIBLEN, R.; VOGEL, F. S. F.; ROEHE, P. M.; ALFIERI, A. A.; PITUCO, E. M. A infecção pelo vírus da Diarréia Viral Bovina (BVDV) no Brasil - histórico, situação atual e perspectivas. Pesquisa Veterinária Brasileira, Soropédica, v. 25, n. 3, p. 125134, 2005.

FUX, R.; WOLF, G. Transient elimination of circulating bovine viral diarrhoea virus by colostral antibodies in persistently infected calves: a pitfall for BVDVeradication programs? Veterinary Microbiology, Barcelona, v. 161, n. 1-2, p. 13-19, 2012.

GRAPHPAD INSTAT. Software. Version 3.0. La Jolla, CA, USA, 2008.

GROOMS, D.; BAKER, J. C.; AMES, T. R. Doenças causadas pelo vírus da diarréia viral bovina. In: SMITH, B. P. Medicina interna de grandes animais. 3. ed. São Paulo: Manole, 2006. p. 707-714.

HOUE, H.; LINDBERG, A.; MOENNING, V. Test strategies in bovine viral diarrhea virus control and eradication campaigns in Europe. Journal of Veterinary Diagnostic Investigation, Athens, v. 18, n. 5, p. 427-436, 2006.

KELLING, C. L.; TOPLIFF, C. L. Bovine maternal, fetal and neonatal responses to bovine viral diarrhea virus infections. Biologicals, London, v. 41, n. 1, p. 20-25, 2013.

LANYON, S. R.; HILL, F. I.; REICHEL, M. P.; BROWNLIE, J. Bovine viral diarrhoea: Pathogenesis and diagnosis. The Veterinary Journal, London, v. 199, n. 2, p. 201-209, 2014.

LAUREYNS, J.; RIBBENS, S.; KRUIF, A. Control of bovine virus diarrhea at the herd level: reducing the risk of false negatives in the detection of persistently infected cattle. The Veterinary Journal, London, v. 184, n. 1, p. 21-26, 2010.

PILZ, D.; ALFIERI, A. F.; ALFIERI, A. A. Comparação de diferentes protocolos para a detecção do vírus da diarréia viral bovina por RT-PCR em grupos de sangue total e de soro sangüíneo, artificialmente contaminados. Semina: Ciências Agrárias, Londrina, v. 26, n. 2, p. $219-$ 228, 2005.

PILZ, D.; ALFIERI, A. F.; ALFIERI, A. A. RT-PCR em pools de soros sangüíneos para o diagnóstico da infecção aguda e de animais persistentemente infectados pelo vírus da diarréia viral bovina. Arquivo Brasileiro de Medicina Veterinária e Zootecnia, Belo Horizonte, v. 59, n. 1, p. 1-7, 2007.

REED, L. J.; MUENCH, H. A simple method of estimating fifty per cent endpoints. The American Journal of Hygiene, Toronto v. 27, n. 3, p. 493-497, 1938.
RIBEIRO, J. N.; PEREIRA, A. Aspectos da epidemiologia da infecção e persistência do vírus da diarreia viral bovina em explorações de bovinos leiteiros. Revista Portuguesa de Ciências Veterinárias, Lisboa, v. 99, p. 41-51, 2004.

RIDPATH, J. F. Bovine viral diarrhea virus: global status. The Veterinary Clinics of North America: Food Animal Practice, Philadelphia, v. 26, n. 1, p. 105-121, 2010.

RIDPATH, J. F.; NEILL, J. D.; CHASE, C. C. L. Impact of BVDV infection of white-tailed deer during second and third trimesters of pregnancy. Journal of Wildlife Diseases, Iowa, v. 48, n. 3, p. 758-762, 2012.

SARRAZIN, S.; DEWULF, J.; MATHIJS, E.; LAUREYNS, J.; MOSTIN, L.; CAY, A. B. Virulence comparison and quantification of horizontal bovine viral diarrhoea virus transmission following experimental infection in calves. The Veterinary Journal, London, v. 202, n. 2, p. 244-249, 2014.

SCHEFERS, J.; MUNOZ-ZANZI, C.; COLLINS, J. E.; GOYAL, S. M.; AMES, T. R. Serological evaluation of precolostral serum samples to detect bovine viral diarrhea virus infections in large commercial dairy herds. Journal of Veterinary Diagnostic Investigation, Athens, v. 20, n. 5, p. 625-628, 2008.

STOKSTAD, M.; LOKEN, T. Pestivirus in cattle: experimentally induced persistent infection in calves. Journal of Veterinary Medicine, Malden, v. 49, n. 10, p. 494-501, 2002.

THRUSFIELD, M. V. Epidemiologia veterinária. 2. ed. São Paulo: Roca. 2004. 556 p.

ZIMMER, G. M.; MAANEN, C. V.; GOEY, I.; BRINKHOF, J.; WENTINK, G. H. The effect of maternal antibodies on the detection of bovine virus diarrhoea virus in peripheral blood samples. Veterinary Microbiology, Barcelona, v. 100, n. 3-4, p. 145-149, 2004.

VALZ, P. H.; GROOMS, D. L.; PASSLER, T. RIDPATH, J. F.; TREMBLAY, R.; STEP, D. L.; CALLAN, R. J.; GIVENS, M. D. Control of bovine viral diarrhea virus in ruminants. Journal of Veterinary Internal Medicine, Louisiania, v. 24, n. 3, p. 476-486, 2010.

WORLD ORGANIZATION FOR ANIMAL HEALTH - OIE. Bovine viral diarrhoea. In: Manual of diagnostic tests and vaccines for terrestrial animals. Paris, 2008. chapter 2.4 .8 , p. 1-22. Available at: <http://www.oie.int/ fileadmin/Home/eng/Health_standards/tahm/2.04.08 BVD.pdf>. Accessed at: 14 feb. 2015. 